\title{
Relationship between Financial Indicators and Foreign Direct Investment in Eswatini
}

\author{
Nosipho Pearl Hlophe And Kalu O. Emenike \\ Department of Accounting and Finance Faculty of Commerce University of Eswatini \\ Private Bag No 4, Kwaluseni M201 Kingdom of Eswatini
}

\section{Article Info}

Keywords:

Exchange rate; Foreign direct investment; Interest rate, and Inflation rate

ISSN (print) : 2598-7763 ISSN (online): 2598-7771

$\square$ Corresponding Author: Nosipho Pearl Hlophe: Tel. /Fax.

E-mail: noshpearl@gmail.com (cc) BY-NC-SA

\begin{abstract}
Abtract
This study evaluates relationship between financial indicators and foreign direct investment (FDI) in Eswatini. The objective was to establish whether there exists significant relationship as well as causality between FDI and exchange rate, interest rate and inflation rate using annual data from 1980 to 2019. Unit root properties of the data were analysed using the Augmented Dickey Fuller test which showed that all data was stationary at first difference. The correlation results showed that there is a positive significant relationship between FDI and the exchange rate. The results also showed a positive but weak correlation for the interest rate as well as a weak negative correlation for inflation rate. The Granger causality test shows evidence of unidirectional causal relationship from exchange rate to FDI. In order words, exchange rate Granger causes FDI in Eswatini. We also document evidence of unidirectional causality from inflation rate to FDI. We recommend amongst others that Eswatini monetary authorities should continue to adopt fiscal and monetary policies that would contain inflation in the economy.
\end{abstract}

Citation: Hlophe, P.N., and Emenike, O.K. (2020). Relationship between Financial Indicators and Foreign Direct Investment in Eswatini. AFRE Accounting and Financial Review, 3 (1)

\begin{abstract}
Abstraks
Studi ini mengevaluasi hubungan antara indikator keuangan dan investasi asing langsung (FDI) di Eswatini. Tujuannya adalah untuk menentukan apakah ada hubungan yang signifikan serta kausalitas antara FDI dan nilai tukar, tingkat bunga dan tingkat inflasi menggunakan data tahunan dari 1980 hingga 2019. Properti akar unit dari data dianalisis menggunakan uji Augmented Dickey Fuller yang menunjukkan bahwa semua data stasioner pada perbedaan pertama. Hasil korelasi menunjukkan bahwa ada hubungan positif yang signifikan antara FDI dan nilai tukar. Hasilnya juga menunjukkan korelasi positif tetapi lemah untuk tingkat bunga serta korelasi negatif yang lemah untuk tingkat inflasi. Uji kausalitas Granger menunjukkan bukti hubungan kausal searah dari nilai tukar ke FDI. Dengan kata lain, nilai tukar Granger menyebabkan FDI di Eswatini. Kami juga mendokumentasikan bukti kausalitas searah dari tingkat inflasi ke FDI. Kami merekomendasikan antara lain bahwa otoritas moneter Eswatini harus terus mengadopsi kebijakan fiskal dan moneter yang akan mengandung inflasi dalam perekonomian.
\end{abstract}

JEL Classification: F21, G23, O16

DOI: https://doi.org/10.26905/afr.v3i1.4385

\section{INTRODUCTION}

Foreign Direct Investment (FDI) is a type of cross border investment in which an investor in one economy establishes a lasting interest in, and has a significant degree of influence over an en- terprise in another economy. It is an investment made by a firm or individual of one country into business interests in another country (OECD, 2020). FDI started as a channel for transferring resources between countries and a means of controlling the use of these resources and comple- 
mentary local inputs. The MNE set up was preferred by capital-intensive primary products and technology-intensive manufacturing sector, who provided the financing, organized the supply of technology and management of the MNEs. Expatriates invested or raised finances in the home country and purchased controlling equity investment in the foreign country. The Classical Theory of trade supports this assertion (Krugman, Obstfeld \& Melitz, 2012) Saini \& Singhania, 2018; Emenike \& Amu, 2019). As FDI evolved, investors were setting up foreign branches of enterprises that were already operational in their home countries. A significant growth was experienced during and after the Second World War where bigger corporations were moving their operations to other countries that were economically and politically stable. During this period there was more of enforced divestment and nationalization of primary product investment and setting up of international producers' cartels without the power of the host country economics being revealed. The Product Life Cycle theory by Venon (1966) adds on to state that depending on the stage of the life cycle of production, it may be decided to export or even produce in another country.

In the last four decades there has been a shift, as observed by scholars, from the traditional import substituting and resource based FDI to that designed to promote an integrated structure of MNEs (Paul \& Feliciano-Cestero, 2020). The last 20 years has seen an increase, not only in the importance of joint ventures and non-equity resource flows but of liquidation and voluntary divestment, especially by US MNEs to developing countries. The involvement is more in low or mature technology sectors in which barriers to entry are falling in response to the move towards globalization. Buckley and Casson (1976)'s internalization theory asserts that there are factors within the firm that encourage the investor to expand internationally. FDI has become the territorial expansion of business activities to advance the interests of the investor, normally to secure the highest rate of return on investment. Developing countries are recognizing the advantages of FDI to their economies and are competing to attract more FDI.

Global foreign direct investment has been declining and it continued to slip from 2015 for three consecutive years, dropping by $13 \%$ to US $\$ 1.3$ trillion in 2018. This decline was largely emanating from the first and second quarter activities that saw the US multinational enterprises returning their business to the US due to the new tax laws that were implemented requiring that the multinational enterprises (MNEs) be taxed twice, in the foreign country and the home country. Foreign corporations that are owned by Unites States (US) citizens were previously not subjected to US taxes but only paid taxes in the host country unless it was income received in the form of dividends. Foreign direct investment (FDI) inflows to developed countries reached the lowest in 14 years, with a decline of $27 \%$. FDI flows to Africa increased by $11 \%$ to $\$ 46$ billion despite the declines in many larger recipient countries. The increase could be attributed to the continued resource seeking inflows, diversification of investments and the recovery in South Africa after several years of low level inflows. This positive change resulted in an increase from a deficit of $\$ 1.34$ million in Eswatini to an inflow of $\$ 0.54$ million breaking the persistent decline from year 2015 (OECD, 2020).

The Kingdom of Eswatini is a relatively small country that is constantly engaging different strategies in its endeavour to increase foreign direct investment. The country is party to a number of conventions and has accomplished and maintained trade agreements with other countries, regionally and internationally, to increase the trade areas and the market size. Betchoo (2019) maintains that governments and bilateral agreements are the first issues that should be considered when developing business beyond borders. A few of the trade agreements signed by the country include SACU, COMESA, African Continental Free trade, Economic Partnerships Agreement, Tripartite Free Trade Area, and AGOA. Eswatini is currently ranked first position in Africa and thirty-two in the world, in Trading across Borders by the World Bank Ease of Doing Business Index. In 2017, it was ranked first in the Sub Saharan region in the 2017 Index of Economic Freedom. (Authority, 2019). The Eswatini Investment Promotion Agency (EIPA) was formed in 1998 to promote and facilitate local and foreign direct investment and trade in the country. In its effort to encourage FDI in the country, EIPA has incentives that are often customized for the different industries. There are exemptions from import duty offered to new investors on machinery and equipment and on the raw materials for manufacturing goods that are brought into the country. Generous tax allowances are also offered to new firms, including a ten-year exemption from withholding tax on dividends and a low corporate tax rate of up to $10 \%$ on approved in- 


\section{Relationship between Financial Indicators and Foreign Direct Investment in Eswatini Nosipho Pearl Hlophe And Kalu O. Emenike}

vestment projects. Firms that engage in manufacturing industry in the country are offered with purpose built factory shells at subsidized rates, in the fully serviced industrial sites of the country (Eswatini Investment Promotion Authority, 2019)

Despite all efforts made by the Government of Eswatini to increase the inflow of Foreign Direct Investment in the country, statistics are showing a continued instability in the past ten years. Data show that for the year 2010 FDI inflows were at \$135.6 million dropping to \$26.5 million in 2012 and continued to fluctuate, reaching \$-57.8 million in 2017. The Swazi Lilangeni/US dollar (SZL/US\$) exchange rate, on another note, has continuously been depreciating from SZL7.32/\$ in 2010 to SZL14.71/ $\$$ in 2016. This implies that about half of its value was lost in a 6-year period. The inflation rate showed great increase from $4.509 \%$ in 2010 to $8.9 \%$ in 2012 , which is almost double. The real interest rate has been continuously fluctuating (The World Bank, 2020; Central Statistics Office, 2020). In the 2015/6 fiscal year the Government of Eswatini developed the country's Industrial Development Policy which looked at areas that government had to consider to improve the investment climate and encourage foreign direct investment. In all the strategies stated, there is none that speaks to the financial indictors as areas of consideration in the implementation plan to achieve that goal. The effects of these financial indicators to the economy are real and consequential; hence they should be investigated in the context of FDI. An investigation to ascertain the impact of financial variables on FDI inflows, therefore, becomes crucial to understand whether they are the reasons for the fluctuations. Past studies have been carried out to assess the determinants of FDI (Masuku \& Dlamini, 2009), and examine the examined benefits and drawbacks of foreign direct investment in Eswatini (Joubert, 2012), but no study has concentrated on linkage between financial indicators and FDI in Eswatini, which is a gap that needs to be addressed.

The purpose of this study therefore was to evaluate the relationship between financial indicators and foreign direct investment in Eswatini.This study will close the gap in previous studies that have been carried out on the subject in Eswatini. It will be a great contribution to the body of knowledge on the subject to future scholars. For the country to be able to attract more foreign direct investments, it is imperative that the policymakers are able to identify the financial indicators that have greater influence on foreign direct investment inflows. This study will be useful to the policy makers as a build up to the development of a model for Eswatini that relates foreign direct investment to the macroeconomic drivers. Foreign investors will also be able to understand the causal relations of the financial indicators on their investment for planning and decision making. The rest of the paper is organised as follows: immediately following this introduction is section 2, which presents brief review of empirical literature. Section 3 contains data and method of analysis. Section 4 presents results from the study and discussions, and section 5 concludes the study.

\section{HYPOTHESIS DEVELOPMENT}

Several studies have been undertaken by scholars on the relationship between foreign direct investment and financial indicators in developing economies. Wijeweera and Mounter (2008) for example analysed how FDI inflows respond to market size and performance, trade openness, labour cost indicators, exchange rate and interest rates for the period 1950 to 2004 . The results show amongst others that exchange rate has an inverse relationship with FDI in the short run but positive in the long run, and FDI and interest rates has an inverse relationship in Sri Lanka. A similar Pakistan study by Malik and Malik (2013) reported that the coefficients of GDP, inflation and exchange rate are positive when tested at $1 \%$ significance level. They concluded that the macroeconomic indicators have a significant positive impact on FDI inflows in Pakistan. Alshamsi, Hussin and Azam (2015) studied the impact of inflation rate and GDP per capita on inward foreign direct investment inflows in United Arab Emirates (UAE) for the 1980 to 2013 periods, and documented evidence of no significant effect of inflation on FDI inflows whereas GDP per capita proxy used for market size has a significantly positive impact on FDI inflows. An Indian study by Vanita, Rifika and Varun (2015) explored the relationship between FDI and six macroeconomic variables namely; exchange rate, inflation, Index of industrial production, interest rate, trade openness and S\&P CNX 500 equity index. They conclude that all the macroeconomic variables showed a positive and significant correlation with FDI except for exchange rate and interest rate which have a negative and significant correlation with FDI.

Many studies on FDI and financial indica- 
tors have also been conducted using African data. Omankhanlen (2011) examined the effect of exchange rate and inflation on foreign direct investment and their relationship with economic growth in Nigeria using annual data from 1980 to 2009. The study revealed amongst others that Inflation has no major effect on FDI but that exchange rate has a significant and positive effect on FDI. In a related study, Benson, Eya and Yunusa (2019) examined the effect of exchange rate, inflation and interest rates on FDI in Nigeria for the period 2006 to 2018. They report that a positive significant relationship exists between exchange rate and FDI. The long run co-integrating equation showed that a negative relationship exists between interest rate and FDI although not statistically significant. Inflation was negatively related to FDI in the long-run. Faroh and Shen (2015) carried out a study aimed at examining the impact of interest rate on FDI flow in Sierra Leone. It was conducted from time series data for the period of 1985 to 2012 in the following variables were considered: GDP, used as a proxy for market size, Inflation for economic stability, exchange rate for financial market viability, interest rate for Central bank monetary policy tool and trade volume as a proxy for trade openness. From the analysis, trade openness and exchange rates were found to be the key determinants of FDI inflow, having positive significance. Others variables, such as inflation, GDP and interest rate, were found to be insignificant factors causing the variability of FDI flows. Enu, Havi and Attah-Obeng (2013) examined the determinants of foreign direct investment inflows to Ghana between the periods 1980 to 2012. The results showed that there is unilateral directional between FDI and GDP growth, exchange rate and GDP growth. There was also bidirectional causality between exchange rate and FDI, Inflation and GDP growth, trade openness and GDP growth and also between trade openness and inflation.

In a Kenyan study, Ndanu and Ocharo (2018) reported that real interest rates and exchange rates have negative and significant influence on FDI inflows into Kenya; but inflation has insignificant influence on FDI.

$\mathrm{H}_{1}$ : There is no significant relationship between the interest rate and foreign direct investment in Eswatini

$\mathrm{H}_{2}$ : There is no significant relationship between the inflation rate and foreign direct investment in Eswatini

$\mathrm{H}_{3}$ : There exist no significant relationship between the exchange rate and foreign direct investment in Eswatini

Dondashe \& Phiri (2018) examined macroeconomic determinants of FDI for the South African economy using GDP per capita, inflation rate, government size, real interest rate and terms of trade. The results showed that with the exception of inflation; real interest rate, GDP per capita, government size and terms of trade exert a positive long run effect on FDI in South Africa. A related study by Masipa (2018) sought to ascertain the relationship between FDI and economic growth in South Africa for the 1980 - 2014 periods. The variables analysed were FDI inflows, GDP growth rate, trade openness, real effective exchange rate and government expenditure. The results showed amongst others that a percentage increase in the exchange rate was observed as leading to $11.96 \%$ decline in economic growth. The study concluded that an increase in government spending displaced the investment in the economy (the crowding effect). The nature of the relationship supported the traditional notion that attraction of FDIs and increase in GDP enhance economic growth in South Africa.

In Eswatini, Masuku \& Dlamini (2009) carried out a study on the determinants of foreign direct investment for the period 1980 to 2001 . The variables used in the study were FDI inflows, as the dependent variable and the independent variables included the size of the domestic market, openness of the economy, infrastructure, and attractiveness of the domestic market, external economic stability and internal economic stability. They reported that $76 \%$ of the variation in FDI is explained by economic openness to foreign trade, infrastructure, internal and external economic stability as well as size and attractiveness of the domestic market of the previous year. FDI inflows were positively influenced by economic stability, infrastructure, internal economic stability, and openness of the economy, but negatively influenced by attractiveness of the domestic market, and the size of the domestic market.

$\mathbf{H}_{4}$ : There is no causal relationship between the financial indicators and foreign direct investment in Eswatini

\section{DATA AND METHOD}

\section{Nature and sources of data}

This study adopted a quantitative research method in analysing the relationship between three financial indicators and foreign direct investment inflows. The study used time series data 


\section{Relationship between Financial Indicators and Foreign Direct Investment in Eswatini Nosipho Pearl Hlophe And Kalu O. Emenike}

on the variables for the period 1980 to 2019. A correlational research design, which measures a relationship between two variables without the researcher controlling either of them, was adopted. Secondary data was used for this study. Annual time series data on the inflows of FDI and the financial indicators, namely real interest rate, inflation rate and exchange rate, was sourced from the World Bank development indicators website, the Central bank of Eswatini, and the Central Statistics Office of Eswatini.

\section{Model specification}

Based on the empirical review, a linear form of the model is presented as:

$$
\mathrm{FDI}=\mathrm{f}(\mathrm{INT}, \mathrm{INF}, \mathrm{EXRATE})
$$

This means that the study seeks to describe the FDI inflows as a function of interest rate, inflation and exchange rate. The linear multiple regression model is displayed as:

$$
F D I_{t}=B_{o}+B_{1} I N T_{t}+B_{2} I N F_{t}+B_{3} E_{X R A T E}+\varepsilon t
$$

Where $\mathrm{FDI}_{\mathrm{t}}$ is the Foreign Direct Investment in time $t$ $\mathrm{B}_{0}$ is the intercept, $\mathrm{B}_{\mathrm{i}}$ the coefficients, INT is the interest rate, INF is the inflation, EXRATE is the exchange rate and $\varepsilon t$ is the error term assumed to be normally and independently distributed with zero mean and captures all other explanatory variables that influence foreign direct investment but are not captured in this model.

\section{Method of Data Analysis}

\section{Unit Root Test}

Before running the correlation analysis the variables must be tested for stationarity. In testing for stationarity the Augmented -Dickey Fuller (ADF) test was applied in levels and differenced to establish the presence of a unit root and the order of integration. This test is to ensure that all the variables are integrated in the same order to avoid spurious results. It is based on the model:

$y_{t}=\alpha+\gamma t+\sum_{i=1}^{p} \beta_{i} y_{t-i}+\varepsilon_{t}$

$\Delta y_{t}=\mu+\gamma t+\alpha y_{t-1}+\sum_{i=1}^{p} \beta_{i} \Delta y_{t-i}+\varepsilon$

Where Yt is the variable tested for unit root; $\rho$ is the lag length; $\mathrm{t}$ is the time trend variable while, $\Delta$ is the difference operator, $\boldsymbol{\alpha}$ and $\mu$ are the constant terms and $\varepsilon_{\mathrm{t}}$ is the error term.

The null hypothesis is that the series has a unit root and is non stationary. The decision rule is based on 5\% significance level and the p-value. If p-value $>0.05$ the null hypotheses cannot be rejected, the data has a unit root and is non stationary. If p-value $<=0.05$ the null hypotheses is rejected, the data does not have a unit root and is stationary (Emenike, 2015).

\section{Correlation Analysis}

The interrelationship between the variables was examined. Correlation analysis observes the existing association or relationship between the variables (Evans, 1996). The measure for this relationship from the sample is called the sample (Pearson) correlation coefficient, denoted by $r$. The formula for estimating $\mathrm{r}$ is:

$$
r_{x y}=\frac{n \sum x_{i} y_{i}-\sum x_{i} \sum y_{i}}{\sqrt{n \sum x_{i}^{2}-\left(\sum x_{i}\right)^{2}} \sqrt{n \sum y_{i}^{2}-\left(\sum y_{i}\right)^{2}}}
$$

Where: $r_{x y}$ is the Pearson correlation coefficient between variable $\mathrm{x}$ and $\mathrm{y}, n$ is the number of observations, $x_{i}$ is the value of $x$ for the $i$ th observation, and $y_{i}$ is the value of $y$ for the $i$ th observation

The results of this analysis is the Pearson correlation coefficient whose values range from -1 to +1 , signifying the strength or extent and direction of association between two variables. A correlation coefficient of -1 signifies a perfect negative relationship, a +1 indicates that the two variables perfectly positively related while 0 indicates that there is no relationship between the two variables (Gogtay \& Thatte, 2017). In testing hypothesis, the significance of the relationship between variables is established through the $p$-value results. Thus, the null hypothesis is rejected if $\rho \leq 0.05$.

\section{Granger Causality Test}

The Granger Causality test was run to test if the lagged values of the independent variables explain the change in the dependent variable and also determine the direction. Following Emenike (2015), we specify the Granger causality as follows:

$$
\begin{aligned}
& Y_{t}=\sum_{i=1}^{n} \alpha_{i} Y_{t-i}+\sum_{j=1}^{n} \beta_{j} X_{t-j}+u_{1 t} \\
& X_{t}=\sum_{i=1}^{n} \lambda_{i} Y_{t-i}+\sum_{j=1}^{n} \sigma_{j} X_{t-j}+u_{2 t}
\end{aligned}
$$

The first equation postulates that the current $Y_{t}$ is related to its past values as well as that of $X_{t}$ and vice versa in the second formula. Unidi- 
rectional causality from $X_{t}$ and $Y_{t}$ is indicated if the estimated coefficient on the lagged $X_{t}$ are statistically different from zero as a sum $\left(\sum \beta_{j} \neq 0\right)$ and the set of estimated coefficient on the lagged $Y_{\mathrm{t}}$ are statistically different from zero $\left(\sum \lambda_{\mathrm{i}} \neq 0\right)$ (ElemUche, Omekara, \& Nsude, 2018). For the granger causality F-test with the null $X_{t}$ does not Granger-cause $Y_{t}$ and the converse, the decision rule is to reject the null if F-stat is greater than the $f$-value.

\section{RESULTS}

\section{Descriptive statistics}

In this section of the study a detailed descriptive analysis will be set and the trends of the dependent and the different explanatory variables will be recognised. The variables can be described using both descriptive statistics and trends as they are time series variables that have an annual frequency, with the independent variables calculated as an average of 12 months, from January to December of each year. The Jarque-Bera probability has the null hypothesis that the series is normally distributed, to which if the p-value is small the null hypothesis is rejected. The descriptive statistics show Jarque-Bera p-values greater than the significance level for foreign direct investment $(p=0.9977)$, exchange rate $(p=0.2440)$ and inflation rate (0.0808), thus failing to reject the null hypothesis. However, the inflation rate has $\mathrm{p}=$ 0.0069 , to which the null hypothesis is rejected.

The FDI graph shows a very irregular trend on FDI in the country, with a minimum of US\$ (60 190680 ) in 2003. This means that there was more divestment compared to investments. It is noted that from a negative value, the rise becomes an instant boom than gradual growth. This is observed in 1993 and 1994, 2003 and 2004, 2005 and 2006 and 2017 to 2019. In 2019 the maximum value was observed at US\$168183134.

The Lilangeni/Dollar exchange rate has been on a depreciatory trend since the 1980's, though there was a false recovery in the years 2000 to 2010. This is shown by the upward trend in the graph over the study period (1980-2019). Recent trends show that the worst position the exchange rate has assumed annually is SZL14.70 per Dollar (Maximum), and the best the exchange rate has assumed was SZL0.78 per dollar (Minimum) in back in the days in 1980 .

The interest rate on the other hand shows that a maximum interest savings have been earned in Eswatini over the duration of the study was 13.81 percent, and that was in 1985. The minimum interest savings have attracted in Eswatini was 12.18 percent and that was is 1990 . Over the period 1980 to 2019, savings have attracted an average interest rate of 4.43 percent. Trends for the interest rate shows that it has fluctuated around $5 \%$ for the duration of the period on study, showing a very low interest rate thus reducing the enthusiasm for saving in the country.

Inflation in Eswatini reached highs of 20.46 percent (Maximum) in 1985, whilst it reached its lowest point in 2019, where it recorded 2.6 percent (Minimum). Over the period, inflation has averaged 4.43 percent, which is well within the South African target of 3-6 percent. This shows that inflation has been fairly stable on the review period though over the years it has been fluctuating. The lows of 2.6 percent show the effect of fiscal policy together with monetary policy in fighting inflation. This data was transformed to natural $\log$ before the tests were conducted.

\begin{tabular}{|c|c|c|c|c|}
\hline & $\begin{array}{l}\text { FDI_INFL } \\
\text { OWS }\end{array}$ & EXCR & INF & INT \\
\hline Mean & 49618226 & 6.120 & 9.635 & 4.432 \\
\hline Median & 44038686 & 6.234 & 7.962 & 5.037 \\
\hline Maximum & 1.68 & 14.711 & 20.462 & 13.811 \\
\hline Minimum & -60190680 & 0.779 & 2.6 & -12.183 \\
\hline Std. Dev & 52219946 & 4.036 & 4.699 & 5.641 \\
\hline Skewness & 0.0171 & 0.562 & 0.869 & -1.04 \\
\hline $\begin{array}{l}\text { Kurtosis } \\
\text { Jarque- }\end{array}$ & 2.961 & 2.344 & 3.030 & 4.270 \\
\hline Bera & 0.005 & 2.821 & 5.032 & 9.943 \\
\hline Probability & 0.998 & 0.244 & 0.081 & 0.007 \\
\hline $\begin{array}{l}\text { Sum } \\
\text { Sum Sq. }\end{array}$ & 1.98 & 244.812 & 381.447 & 177.293 \\
\hline $\begin{array}{l}\text { Dev } \\
\text { Observa- } \\
\text { tions }\end{array}$ & 1.06 & 635.379 & 861.350 & 1240.988 \\
\hline
\end{tabular}

\section{Unit Roots Test}

Prior to running any linear analysis on the data, it is important for the study to ensure that the variables to be used are tested for stationarity. This is to make sure that the variables give better results in the analysis and to ensure that the regression is not spurious. The study used the Augmented dickey-fuller (ADF) test for stationarity testing of the variables. This is to test the null hypothesis of the existence of a unit root in the data (Non Stationarity). The variables were initially tested at level and the results of the test 
are shown in Table 2.

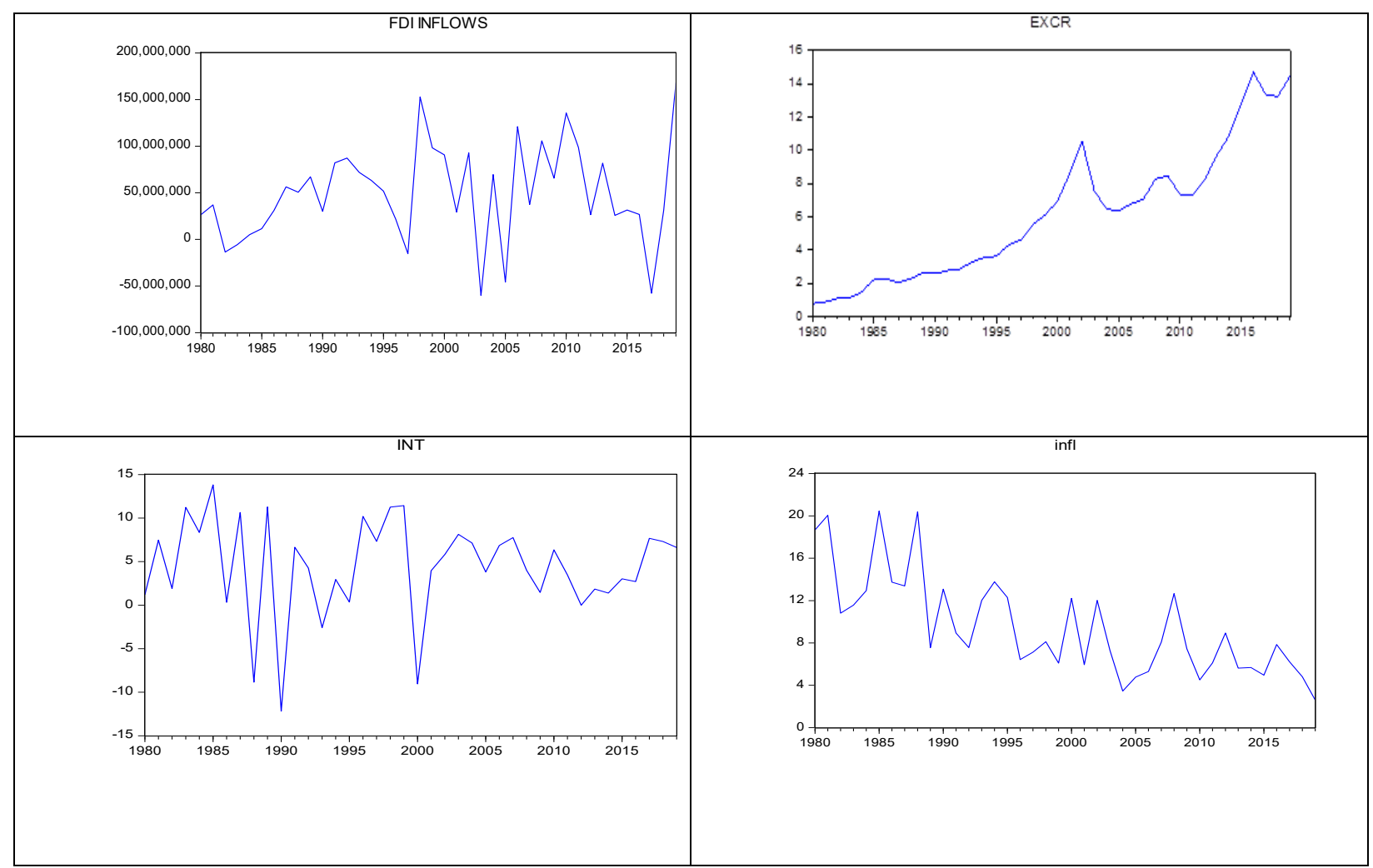

Figure 1 Trends (FDI, exchange rate, interest rate, inflation rate)

Table 2: Unit root test results - at level

\begin{tabular}{lcll}
\hline \multicolumn{1}{c}{ Variable } & $\begin{array}{c}\text { Differ- } \\
\text { encing }\end{array}$ & $\begin{array}{l}\text { ADF } \\
\text { Statistics }\end{array}$ & Value \\
\hline $\begin{array}{l}\text { Exchange } \\
\text { Rate(Lilangeni/ }\end{array}$ & At Level & -2.1263 & 0.2359 \\
Dollar) & & & \\
FDI inflows & At Level & -6.4430 & .0000 \\
Inflation rate & At Level & -2.9367 & 0.0503 \\
Interest rate & At Level & -6.7940 & 0.0000 \\
\hline
\end{tabular}

Results from Table 1 show that FDI inflows and interest rate are stationary at level and the exchange rate, as well as, the inflation are have a unit root. The $\mathrm{p}$-values for FDI inflows and interest rates are less than the significance level of 0.05, both estimated at 0.000 respectively. This, therefore, means there is significant information to reject the null hypothesis of the existence of a unit root in these variables. On the other hand, the $\mathrm{p}$ values for the exchange rate and the inflation rate are greater than the significance level of 0.05 , estimated at 0.2359 and 0.0503 , respectively. This implies that there is no sufficient evidence against the null hypothesis, hence the failure to reject the null hypothesis of existence of a unit root. The study differenced these variables and further tested it for unit root after differencing. Results of the ADF test at first difference are shown in Table 3.
Table 2: Results of ADF test at First difference

\begin{tabular}{llll}
\hline \multicolumn{1}{c}{ Variable } & \multicolumn{1}{c}{$\begin{array}{c}\text { Differenc- } \\
\text { ing }\end{array}$} & $\begin{array}{c}\text { ADF } \\
\text { Statistics }\end{array}$ & $\begin{array}{l}\text { P- } \\
\text { Value }\end{array}$ \\
\hline $\begin{array}{l}\text { Exchange } \\
\text { Rate(Rand/Dolla } \\
\text { r) }\end{array}$ & $\begin{array}{l}\text { First dif- } \\
\text { ference }\end{array}$ & -4.6451 & 0.001 \\
FDI Inflows & $\begin{array}{l}\text { First dif- } \\
\text { ference } \\
\text { Inflation rate }\end{array}$ & $\begin{array}{l}\text { First dif- } \\
\text { ference -8.7081 }\end{array}$ & 0.000 \\
Interest rate & $\begin{array}{l}\text { First dif- } \\
\text { ference }\end{array}$ & & \\
& & 0.000 \\
\hline
\end{tabular}

Results from Table 3 show that after first difference, all variables become stationary. The pvalues are estimated at 0.0006 or the exchange rate, 0.0000 for FDI inflows, 0.0000 for the inflation rate and 0.0000 , as well, for the interest rate. These $\mathrm{p}$-values are below the significance level of 0.05, hence we have significant information to reject the null hypothesis of an existence of a unit root in all the variables. This implies that all variables are now ready for linear analysis, therefore, the next section of the chapter will explore the correlation analysis with the aim of assessing the existing linear relationships in the data. 


\section{Correlation analysis}

In this section of the study we seek to describe the nature of the relationship that exists between the variables in addressing the first three objectives of this study. This will be assessed through the use of the Pearson correlation coefficient and p-values. Results of the correlations are shown in Table 4.

Table 3: Results of Correlations

\begin{tabular}{|c|c|c|c|c|c|}
\hline & & DLNFDI1 & DLNINT1 & DLNEXCR1 & DLHINF1 \\
\hline \multirow[t]{3}{*}{ DLNFDI1 } & Pearson Correlation & 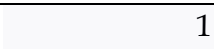 & .013 & $.327^{*}$ & -.030 \\
\hline & Sig. (2-tailed) & & .940 & .045 & .857 \\
\hline & $\mathrm{N}$ & 38 & 38 & 38 & 38 \\
\hline \multirow[t]{3}{*}{ DLNINT1 } & Pearson Correlation & .013 & 1 & .125 & $-.493^{* *}$ \\
\hline & Sig. (2-tailed) & .940 & & .455 & .002 \\
\hline & $\mathrm{N}$ & 38 & 38 & 38 & 38 \\
\hline \multirow[t]{3}{*}{ DLNEXCR1 } & Pearson Correlation & $.327^{*}$ & .125 & 1 & .174 \\
\hline & Sig. (2-tailed) & .045 & .455 & & .297 \\
\hline & $\mathrm{N}$ & 38 & 38 & 38 & 38 \\
\hline \multirow[t]{3}{*}{ DLHINF1 } & Pearson Correlation & -.030 & $-.493^{* *}$ & .174 & 1 \\
\hline & Sig. (2-tailed) & .857 & .002 & .297 & \\
\hline & $\mathrm{N}$ & 38 & 38 & 38 & 38 \\
\hline
\end{tabular}

*. Correlation is significant at the 0.05 level (2-tailed).

**. Correlation is significant at the 0.01 level (2-tailed).

The results show that there exists a significant positive relationship between exchange rate and foreign direct investment inflows at the 0.05 level of significance. This is depicted by the $\mathrm{p}$ value of 0.045 which is less than the significance level, thus the study rejects the third hypothesis that there exist no significant relation between the exchange rate and foreign direct investment inflows in Eswatini. A Pearson correlation coefficient $(r)$ of 0.327 is observed.

The results show that there is no significant relationship that exists between interest rate and FDI inflows, with a p-value of 0.94 which greater than the significance level. A positive Pearson correlation coefficient (r) of 0.13 is observed.

The inflation rate is also shown to have no significant relationship with FDI inflows. The results show a p-value of 0.86 , which is above the significance level of 0.05 . The Pearson correlation coefficient is -0.03 , meaning though insignificant there is a negative relationship between inflation rate and FDI inflows. This, therefore, means that the study fails to reject the first and second null hypothesis.

\section{Causality Analysis}

This section of the chapter explores the causal relationships that exist within the variables considered in the study. The study used the Granger causality test, which is a test that investigates the null hypothesis of each of the economic variables granger causing foreign direct investment inflows into Eswatini. This test addresses the fourth research objective of the study. The results of the test are shown in Table 5.

\begin{tabular}{lccl} 
Table 4: Results of the Granger Causality test extract & & & \\
\hline Null Hypothesis: & Obs & F-Statistic & Prob. \\
\hline DLNFDI1 does not Granger Cause DLNEXCR1 & 36 & 1.10676 & 0.3433 \\
DLNEXCR1 does not Granger Cause DLNFDI1 & & 5.13571 & 0.0118 \\
DLNINT1 does not Granger Cause DLNFDI1 & \multirow{3}{*}{36} & 0.53568 & 0.5906 \\
DLNFDI1 does not Granger Cause DLNINT1 & & 0.00586 & 0.9942 \\
DLHINF1 does not Granger Cause DLNFDI1 & \multirow{3}{*}{36} & 3.24550 & 0.0525 \\
DLNFDI1 does not Granger Cause DLHINF1 & & 0.72315 & 0.4932 \\
\hline
\end{tabular}

The results from the Granger causality test show a p-value of 0.01 , which means that at $5 \%$ significance level, the null hypothesis of exchange rate not granger causing FDI inflows is rejected. There is sufficient evidence in support of the al ternative that the exchange range does granger cause FDI inflows.

It is noted that the results show a p-value of 0.053 for inflation rate not Granger causing FDI inflows. This implies that there is no sufficient 


\section{Relationship between Financial Indicators and Foreign Direct Investment in Eswatini Nosipho Pearl Hlophe And Kalu O. Emenike}

evidence to reject the null hypothesis that the inflation rate does not Granger cause FDI inflows into Eswatini at 0.05 significance level. This, however, does not hold true at $10 \%$ significance level. A study that runs the test at 0.10 significance level would reject the null, since the p-value is below the significance level. Consequently, inflation rate Granger-causes FDI at conventional significance level. The interest rate presented the p-value of 0.59 which is greater than the significance level of 0.05, therefore, implying that interest rate does not Granger cause FDI inflows.

\section{DISCUSSION}

Varying results were obtained from previous studies conducted in the Asia region where Vanita, Rifika and Varum (2015) found India to exhibition a positive significant relationship for inflation and negative significant relationship for exchange rate and interest rate towards FDI. This is contrary to the findings of this study. Malik and Malik (2013), in Pakistan, found a positive significant relationship between FDI and both inflation rate and exchange rate. However, Alshamsi, Hussin and Azam (2015), and Wijeweera and Mounter (2008) in their China and Sri Lanka studies, respectively discovered almost similar results to this study. China showed a weak and positive relationship to FDI, whilst in Sri Lanka showed a positive relation for exchange rate although a negative relation with interest rate.

In the African region, most of the earlier studies reflected similar results to this study. A positive, significant relationship for exchange rate was found in Nigeria by Omankhalen (2011), Ekine and Ajie (2017) and Benson, Eya and Yunusa (2019). Ndanu and Ocharo (2018), in contrast, in their Kenyan study discovered a negative and significant relationship for both interest rate and exchange rate and no significance for inflation rate. Similar results to this study were also observed by Faroh and Shen (2015) in Sierra Leone study as well as Dondashe and Phiri (2019) in South Africa. In most African countries, the exchange rate is observed to have a positive relationship with FDI. Inflation rate is mostly negative and insignificant.

A large number of studies have been conducted, which lead to identifying the determinants of FDI; however, there is no unanimity in accepting any set of explanatory variables that can be regarded as the correct determinants of FDI. Varying results are obtained for the different economies. Masuku \& Dlamini (2009) studied the determinants of FDI inflows in Eswatini, using cointegration and the error correction model. The study showed that $76 \%$ of the variations of FDI inflows could be explained by the model which was looking at FDI inflows as a function of the domestic market, openness of the economy to foreign trade, infrastructure of the host country, attractiveness of the domestic market, external economic stability and the internal economy. Most of these significant variables are dependent on exchange rate and inflation rate. In order words, the import of stable exchange and inflation rates in attracting FDI inflow is established.

\section{CONCLUSIONS AND SUGGESTIONS}

The import of FDI in enhancing liquidity in the domestic economy and bringing significant benefits by creating high-quality jobs, introducing modern production and management practices thereby enhancing economic development has been highlighted in literature. This study evaluated the causal relationship between financial indicators namely exchange rate, interest rate and inflation rate and FDI using simple correlation analysis and Granger causality test for the 1980 2019 study period. The estimates from preliminary analysis data series are first difference stationary. The results from correlation analysis show that interest rate and inflation rate do not have significant relationship with FDI inflows in Eswatini. The results however show evidence that exchange rate has a positive and significant relationship with FDI inflows in Eswatini. Estimates Granger causality test indicates that interest rate do not granger cause FDI inflows in Eswatini. Inflation rate granger causes FDI at the $10 \%$ significance level. The estimates further show evidence of a unidirectional causality from exchange rate to FDI. Hence, exchange rate granger causes FDI inflow in Eswatini, but FDI does not granger cause exchange rate.

One major suggestion to the monetary authorities in Eswatini is continue to adopt fiscal and monetary policies that would contain inflation in the economy. As the correlation results show, inflation has negative association with FDI. Policies that contain it, would favour FDI inflows into Eswatini. In addition, we suggest that the Central Bank of Eswatini should formulate exchange rate policies that enhance stability of Lilangeni. Relative stability of Lilangeni exchange rate is major stimulus to FDI inflows to Eswatini. 
More so, the spread between inflation rate and interest rate should be wide enough to entice foreign investors.

\section{REFERENCES}

Alshamsi, K. H., Hussin, M. R., \& Azam, M. (2015). The impact of inflation and GDP per capita on foreign direct investment; A case of United Arab Emirates. Investmment Management and Financial Innovations, 132141.

Benson, E., Eya, C. I., \& Yunusa, A. (2019). Effect of exchange and interest rates on FDI in Nigeria 2006-2018. International Journal of Contemporary Research and Review.

Betchoo, N. K. (2019). International Business in Emerging Economies. The eBook Company.

Buckley, P. J., \& Casson, M. (1976). The Future of the Multinational Enterprise. London: Macmillan

Central Bank of Eswatini. (2020, February 5). Monetary Policy: Central Bank of Eswatini. Retrieved from Central Bank of Eswatini Website: http://www.centralbank.org.sz/ monetarypolicy/economy/index.php

Central Statistics Office. (2020, February 5). Ministry of Economic Planning and Development. Retrieved from Swaziland Government Website: http://www.gov.sz/ index.php/departments-sp-388544304/124economic-planning-a-development/1835central-statistical-reports

Dondashe, N., \& Phiri, A. (2018). Determinants of FDI in South Africa: Do macroeconomic variables matter? Munich Personal RePEc Archive.https://mpra.ub.unimuenchen.de/id/eprint/83636

Ekine, D. I., \& Ajie, C. O. (2017, October). The relationship between FDI and selected economic indicators in Nigeria: A causaliy approach. Donnish Journal of Economics and International Finance, II(1). Retrieved from http://www.donnishjournals.org/djerf

ElemUche, O., Omekara, C. O., \& Nsude, F. I. (2018). Application of granger causality test in forecasting monetary policy transmission channels for Nigeria. International Journal of Statistics and Applications, VIII(3), 119-128. doi:10.5923/j.statistics.20180803.02

Emenike, K. O. (2015). Response of foreign private investment to public debt in Nigeria. The Romanian Economic Journal, 56(XVIII), 65-86. Emenike, K.O. \& Amu, C. U. (2019). Response of stock market volatility to foreign equity investments. Journal of Contemporary Ecnomic and Business Issues, 6(2), 39-50.

Enu, P., Havi, E. D., \& Attah-Obeng, P. (2013). Impact of macroeconomic factors on foreign direct investment in Ghana: A cointergation analysis. European Scientific Journal, Vol. 9(No. 28).

Eswatini Investment Promotion Authority (2019, November 5). Why invest in Eswatini: Eswatini Investment Promotion Authority. Retrieved from https: //investeswatini.org.sz/why-do-businessin-eswatini/

Evans, J. D. (1996). Straightforward Statistics for the Behavioral Sciences. California: Brook/Cole Publishing.

Faroh, A., \& Shen, H. (2015). Impact of interest rates on FDI: Case study Sierra Leone. International Journal of Business Management and Economic Research, VI(1), 124-132.

Gogtay, N. J., \& Thatte, U. M. (2017). Principles of correlation analysis. Journal of the Association of Physicians of India, 78-81.

Joubert, P. N. (2012). Foreign direct investments in Swaziland: Benefits and drawbacks. International Trade \& Academic Research Conference (ITARC), University of Swaziland, Swaziland.

Krugman, P., Obstfeld, M., \& Melitz, M. J. (2012). International Economics Policy and Theory (9th ed.). Boston: Pearson.

Malik, S., \& Malik, Q. A. (2013). Empirical analysis of macroeconomic indicators as determinants of foreign direct investment in Pakistan. IOSR Journal of Business and Management, VII(2), 77-82.

Masipa, T. S. (2018). The relationship between foreign direct investment and economic growth in South Africa: Vector error correction analysis. Acta Commercii. Retrieved from https://doi.org/ 10.4102/ac.v18il.466

Masuku, M. B., \& Dlamini, T. S. (2009). Determinants of foreign direct investment inflows in Swaziland. Journal of Development and Agricultural Economics, Vol.I(5), 177-184.

Ndanu, M., \& Ocharo, D. K. (2018). Real interest rate, inflation, exchange rate, competitiveness and foreign direct investment in Kenya. American Journal of Economics, III(1), 1-18.

Paul, J., \& Feliciano-Cestero, M. M. (2020). Five decades of research on foreign direct 
investment by MNEs: An overview and research agenda. Elsevier Public Health Emergency Collection. doi:10.1016/ j.jbusres.2020.04.017

OECD. (2020). OECD - ilibrary. Retrieved from OECD Website. Https://data.oecd.org

The World Bank. (2020, February 27). The World Bank Data: Indicators. Retrieved from World Bank Web site: http://www.data. worldbank.org

Omankhanlen, A. E. (2011). The effect of exchange rate and inflation on foreign direct investmentand its relationship with economic growth in Nigeria. Economics and Applied informatics, 1-13.

Saini, N. \& Singhania, M. (2018). Determinants of FDI in developed and developing countries: A quantitative analysis using GMM. Journal of Economic Studies, 45(2), 348-382.

UNCTAD. (2019). World Investment Report 2019. Retrieved from World Inesrtmanet development reportswebsite: https://unctadstat.unctad.org/wds/Repor tFolders

Vanita, T., Rifika, S., \& Varun, B. (2015). Foreign direct investment and macroeconomic factors: evidence from the Indian economy. Asia Pacific Institute of Management, II(1), 111.

Vernon, R. (966). International investment and international trade in the product cycle. Quarterly Journal of Economics, 190-207.

Wijeweera, A., \& Mounter, S. (2008). A VAR analysis on the determinants of FDI inflows: The case of Sri Lanka. Applied Econometrics and International Development. 